\title{
UNIVERSITYOF
}

FORWARD

THINKING

WESTMINSTER用

WestminsterResearch

http://www.westminster.ac.uk/westminsterresearch

Law, necropolitics and the stop and search of young people Flacks, $\mathbf{S}$.

This is a copy of the accepted author manuscript of the following article: Flacks, S. (2018) Law, necropolitics and the stop and search of young people. Theoretical Criminology, DOI: 10.1177/1362480618774036.

The final definitive version is available from the publisher Sage at:

https://dx.doi.org/10.1177/1362480618774036

(C) The Author(s) 2018

The WestminsterResearch online digital archive at the University of Westminster aims to make the research output of the University available to a wider audience. Copyright and Moral Rights remain with the authors and/or copyright owners.

Whilst further distribution of specific materials from within this archive is forbidden, you may freely distribute the URL of WestminsterResearch: ((http://westminsterresearch.wmin.ac.uk/)).

In case of abuse or copyright appearing without permission e-mail repository@westminster.ac.uk 


\section{Law, necropolitics and the stop and search of young people}

\section{Introduction}

Police stop and search powers have been widely criticized for the disproportionate manner in which members of black and ethnic minority communities are targeted (Bowling and Phillips, 2007; Stopwatch, 2013; Equality and Human Rights Commission, 2010; Human Rights Watch, 2010), as well as for the potentially corrosive effects on minors (Flacks, 2017). Stop and searches often fail to meet the necessary threshold for 'reasonable suspicion', with officers citing, for example, the suspicious actions or appearance of an individual as justification for detaining suspects (Bear, 2013; Delsol and Shiner, 2015). The governments of both Scotland and England and Wales have instigated reforms in recent years in order to challenge the disparities in the use of such tactics, and to address deficiencies in reporting (HO, 2014: 2; Murray and Harkin, 2016). Rates appear to have declined as a result, although black people are still significantly more likely to be stopped than whites (for example, four times more likely in London), and arrest rates continue to be low (HMIC, 2015; Dodd, 2017). ${ }^{1}$

Despite many years of criticism, a dearth of evidence on the utility and effectiveness of stop and search as a policing tactic (Bradford, 2015: 119), and various policy revisions and institutional reforms dating back to the 1980s, such powers have been consistently defended by police bodies, politicians, and the judiciary. In Gillan $v$ Commissioner of Police ${ }^{2}$, the (then) House of Lords ruled that the use of powers under s.44 of the Terrorism Act 2000, allowing searches without reasonable suspicion, was lawful, even though the European Court of Human Rights subsequently found that they breached article 5 of the Convention on Human Rights. ${ }^{3}$ More recently, the use of section 60 of the Criminal Justice and Public Order Act 1994 to stop and search a black woman on a bus was ruled acceptable since such powers, in the words of the (now) President of the Supreme Court Lady Hale, provided "great benefits to the public", particularly to black people since "it is mostly

\footnotetext{
${ }^{1}$ Latest figures can be found at http://www.stop-watch.org/

2 [2006] UKHL 12

${ }^{3}$ Gillan and Quinton v United Kingdom (App No 4158/05)
} 
young black lives that will be saved if there is less gang violence in London and other cities." 4 The court disregarded evidence that $\mathrm{s.60}$ searches had a marginal effect on crime yet were "heavily concentrated on black and minority ethnic groups, reinforcing long standing tensions with the police" (Shiner, 2012: 29). The judicial and political defence of stop and search is perhaps more intelligible once the powers are understood less as a crime-fighting tactic and more as "a flexible and highly visible means of...enabling [the police] to contain and, where necessary, criminalise, those who threaten, or are perceived to threaten the social order" (Delsol and Shiner, 2006: 56). 'Fictions' about stop and search, such as its 'necessary' function in preventing crime, thus persist because they "form part of a legitimation strategy which maintains that stop and search is in principle controllable, measurable and that the will exists to control it and assess its effects" (Bradford and Loader, 2016: 32).

The tradition of disavowing complaints against stop and search continued in Mohidin and another $v$ Commissioner of the Police of the Metropolis and others, ${ }^{5}$ concerning a claim against the Metropolitan Police for the abuse suffered by several young people during a police encounter. Although a tortious case heard in the Queen's Bench Division of the High Court, in which the claimants won damages, the judgement provides insights into how such measures are deployed by police, and how their continued, disproportionate deployment has been authorised by the courts. Theoretically building on claims about the social function of stop and search (Bradford and Loader, 2016; Harcourt; 2001), and drawing on Mbembe's (2003) elaboration of biopolitics and biopower (Foucault, 1976), it is argued that the judgement evinces the punitive effect, and 'deathly logic', of the tactic as a technology of governance. The legitimisation and authorisation of stop and search against Black and Asian young men and boys should thus be understood beyond its existing conceptualisation as an effective method of crime control, or even as a mechanism for social control, but as a manifestation of 'necropower' in which investments in imprisonment, social exclusion and segregation are levelled as solutions to the insecurities of the advanced liberal order. Given the 'punitive turn' in juvenile justice (Muncie, 2008), and the importance of age as a vector of urban

\footnotetext{
${ }^{4} R$ (on the application of Roberts) (Appellant) $v$ Commissioner of Police of the Metropolis and another (Respondents) [2015] UKSC 79, para 41.

5 [2015] EWHC 2740 (QB)
} 
exclusion, in addition to, for example, race and class, it is argued below that the exclusion of such populations is thereby naturalised in the process of securing the future and vitality of others. The discussion will first clarify this theoretical framework, exploring its importance for understanding stop and search powers. It will then turn to the ways in which such powers were framed in Mohidin, and how their authorisation reflects the ongoing, necropolitical investment in the disproportionate and punitive policing of young black and Asian men and boys.

\section{Youth, race and the necropolitics of policing}

Work on the "necropolitical" can be traced back to a seminal essay by Achille Mbembe, who wanted to explore "the work of death" (2003:16), as distinct from the analysis of biopolitics ('work of life') undertaken by Michel Foucault (1976). For Foucault, biopower shapes the governance of life at the level of the population with the aim of improving and maximising life for those deemed worthy. Race and racism are central constituents and functions of biopower since they permit the biopolitical technologies and rationalities aimed at 'cleansing' the populace; racism is thus "the precondition for exercising the right to kill" (Foucault, 2003: 256). Mbembe maintains that necropolitics is, like biopolitics, concerned with "the generalized instrumentalization of human existence" but is instead focused on the "material destruction of human bodies and populations" for those earmarked for exclusion, violence and neglect $(2003,14)$. Death is not necessarily literal, or physical, but also/or social, political and civil. Although necro- and biopolitics are two sides of the same coin (Braidotti, 2007), Mbembe argues that death-making is underexplored and analysed in existing conceptions of biopolitical governance. He thus puts forward the notion of necropolitics and necropower

to account for the various ways in which, in our contemporary world, weapons are deployed in the interest of maximum destruction of persons and the creation of death-worlds, new and unique forms of social existence in which vast populations are subjected to conditions of life conferring upon them the status of living dead (Mbembe, 2003: 40). 
Some scholarship has reflected on the ways in which necropower aids understanding of criminological processes, particularly the prison industrial complex (Haritaworn, Kunstman and Posocco, 2014). Life as a prisoner, and former inmate, is in general marked by poor educational and employment opportunities, stigma, exclusion and early death (Scraton and McQulloch, 2009; Prison Reform Trust, 2008; Goldson and Coles, 2008). Given the brutal conditions in many prisons, and the ways in which incarceration functions to subject disenfranchised and discriminated-against populations to social, civil and political death, Sarah Lamble writes that "prison serves as a site of mass warehousing of bodies in conditions that often resemble the death-worlds that Mbembe describes" (Lamble, 2013: 244). The conditions in child prison, where corporal punishment has outlived its demise in adult institutions, and rates of suicide, abuse, bullying, self-harm and mental health problems remain high, have arguably attracted less attention than adult institutions (Willow, 2015). It is, however, the legitimisation of death and suffering for some populations for the ostensible purpose of prolonging the vitality of others that makes the prison a site for necropolitics. A biopolitical lens has often been used within studies of childhood since children's bodies - as materially and symbolically representative of 'human futures' - tend to be the site on which biopolitical battles are fought, and towards which control technologies and rationalities are directed (Rose, 1990; Foucault, 1980: 67). However, less attention has been focused on the (necropolitical) ways in which some children and young people are destined for early death, rather than life and vitality.

Research on policing, when informed by Foucauldian-inspired perspectives, has usually drawn on his early discussion of disciplinary power (following the distinction between government, discipline and security), rather than his extrapolation of biopolitics and its concern with the aggregate control of populations (Foucault, 2007). ${ }^{6}$ For Mariana Valverde (2009), this neglects the explanatory potential of biopolitics, as a variety of security, to account for the ways in which criminal justice initiatives and measures are racialised. On the other hand, criminological studies of necropower have tended to focus on imprisonment rather than extra-penal measures aimed at investigation or prevention. A cautious reader, perhaps wary of over-

${ }^{6}$ Although there are notable exceptions, for example Bernasconi (2010). 
extended neologisms, might doubt whether routine police activities, such as stop and search, should be brought within a necropolitical rubric. Foucauldian perspectives have been especially prone to simplistic interpretation in the field of criminology (Valverde, 2009). Can the policing of young people, harmful as it may be, really be framed as an exercise in death-making? In line with the claims of other researchers about the punitive consequences of policing, it is argued that stop and search indeed serves as a "weapon" in the relegation of some populations to 'bare-life' existences (Mbembe, 2003: 40; Agamben, 1995). Diarmaid Harkin (2015: 44-46) argues that the sociology of punishment should be used to explain and understand the injury and suffering resulting from police actions, claiming that the deprivations (of liberty, autonomy, goods and services and security) that characterise life in prison also extend to policing. He identifies stop and search, and the policing of the young in general, as liable to result in such deprivations and pains. There is some convergence with the observations of other scholars, such as Hannah-Moffat and Lynch (2012: 119), who have called on criminologists to think beyond "what counts as punishment" (see also Zedner, 2016), and with calls for a more "geographically expansive understanding of the carceral" to explain carceral spaces that extend beyond the prison (Brown, 2014).

While Harkin is particularly concerned with popular support for the 'pains of policing', a necropolitical lens positions harmful police encounters within a broader governing framework, and emphasises the destructive (not only painful) consequences of police practices. Stop and search, an institution which has been likened to 'slave patrols' in the US (under the name 'stop and frisk') (Gossett, 2014), is one means of 'marking out' and distinguishing those young bodies deemed worthy, or unworthy, of life. Empirical studies have tended to suggest that police racial prejudice is not necessarily a function of the intrinsic bigotry of individual officers, but reflects societal racism in general (Reiner, 2010: 130). Rob Reiner (2010: 131) thus contends that prior prejudice is reinforced by structural factors, "so [that ethnic minorities] disproportionately become 'police property'." It has been argued that such factors find their provenance in the history of colonialism and its connection with globalisation. As Mbembe (2003: 23) points out, in most cases, the 'selection of races' "are to find their first testing ground in the colonial world." Authors have thus observed that colonialism imbued "all aspects of social life" and continues to be part 
of the contemporary production of both culture and knowledge (Ahmed, 2000: 10; Hall, 1996; Balibar, 2004), and the making of European identity (Gilroy, 2004; Jacobs, 1996). Whereas stop and search powers are considered, in England and Wales, to have originated in the 1824 Vagrancy Act and in the 1839 Metropolitan Police Act (s.66) (Demuth 1978; Delsol and Shiner, 2006), ${ }^{7}$ the over-policing of British minority ethnic communities has its roots in colonial policing tactics in the Caribbean, India and Africa, which were subsequently turned inwards to govern 'domestic colonies' (Fryer, 1984; Howe 1988). The principles of preventative policing informed the creation of colonial police forces in places such as Colombo and Bombay, linked with the expansion of capitalism, long before the establishment of the Metropolitan Police (Brogden, 1987: 11). Stop and search powers in other parts of the world have their roots in colonialism and/or slavery. Weber and Bowling (2011: 354) note that such powers, which in many parts of the world developed from laws against vagrancy, are a "recurring dynamic" and "often provide the starting point for exclusionary projects" (see also Weber and Bowling 2008; Weber, 2011).

Despite these structural foundations, minority victimisation by the police tends to be framed, particularly - as might be expected - by organs of the State, as an accidental or necessary consequence of effective police tactics, or a failure of governance, rather than as a potentially central characteristic of the racial state. Martinot and Sexton (2003: 170) describe this duality as follows:

There are two possibilities: first, police violence is a deviation from the rules governing police procedures in general. Second, these various forms of violence (e.g., racial profiling, street murders, terrorism) are the rule itself as standard operation procedure.

Foucault's observations about surveillance and discipline have been criticised for the failure to adequately reflect on this distinction, and how the tools of examination are laced with racial bias since they comprise a fundamental building block, or 'opening

\footnotetext{
7 It was following extensive criticism of the former (ss. 4 and 6; the 'sus' laws) against people from minority ethnic communities during the 1970s, and particularly young black people, that the Police and Criminal 7 Evidence Act 1984 (PACE) was enacted to curtail police incursions into 'suspect communities' (Scrap Sus Campaign, 1979)
} 
gesture', in the construction of Western modernity (Sexton, 2007: 198). It has thus been argued that he "universalises the body of the white, propertied male" by eliding the violence perpetrated against blacks, such as by police, in the name of the sovereign and through regimes of slavery and colonialism (James, 1996: 25). As a consequence, Joy James (1996: 24) suggests that Discipline and Punish, in particular, "contributes to the erasure of racist violence" and "vanquishes historical and contemporary racialized terror, punishments, and control" (see also Stoler, 1996). However, although Foucault, in his subsequent elaboration of biopolitics, argues that there has been a re-constitution of "sovereignty's old right" of taking life/letting live with a new power to make live/let die, he does not claim that the latter had replaced the former - only 'penetrated' and 'permeated' it (Foucault, 2003: 241). Mbembe also formulates necropolitics as an extension of biopolitics rather than a break from it, and seems to consider Foucault's work to be consistent with theoretical expositions of both the racial foundations of sovereign punishment and the centrality of colonisation to the making of racialised bodies (Gilroy, 1997; Reid, 2008: 87). In suggesting that our global political economy is now characterised as much by the necropolitical 'living dead' as by the biopolitical living life, however, he argues that this process of 'letting die' is not an accidental by-product of biopolitics but rather a constituent of the racial instrumentalization of life-giving. A necropolitical perspective thus provides scope for building on Foucault's critique of sovereignty and its relation to war and biopower (Mbembe, 2003: 11-12), with a more radical account of the biologisation of racism within policing practices.

Mbembe forges connections between biopower and two other concepts, the state of exception and the state of siege, examining how they become the "normative basis for the right to kill" (Mbembe, 2003: 16). In the colony, terror and cruelty are thus conflated with reason in circumstances in which "'peace' is more likely to take on the face of 'war without end'” (Mbembe, 2003: 23). The routine and disproportionate deployment of 'exceptional' stop and search powers under counter-terrorism legislation, ${ }^{8}$ which did not require 'reasonable suspicion', discussed further below, illustrates the ways in which destructive police tactics are similarly deployed in the name of peace (Shiner, 2015: 38). The rhetoric used in justifying stop and search

${ }^{8}$ Section 44 of the Terrorism Act 2000, now repealed. 
powers more generally is frequently rooted in war metaphors, explained in part by their emotive currency within 'populist' approaches to punitive policies (Steinert, 2003), but also evincing the racially-imbued function of policing as a perpetual battle against the 'enemy within'. Politicians have thus called such powers "an extremely important weapon in the armoury of the police, ${ }^{9}$ news organisations run reports advocating the use of such tactics as part of the "battle for the streets," ${ }^{10}$ and officers insist they are a "brilliant tool in our armoury." 11 The use of war language in general positions the tactic as a celebrated power in the push for sovereign control over contested, besieged terrain where the causalities can be rationalised according to an ideological - and entirely justified - governing mission.

\section{The harms of stop and search}

There are a variety of ways in which stop and search, and police powers in general, as both instruments and tactics of 'war', can contribute to the 'slow death' (including social, civil, political and physical) of young people in certain communities. First, drawing on decades of research into the effect of policing on young people, it has been argued that stop and search practices have particularly deleterious consequences for the young, encouraging offending, facilitating entry into the criminal justice system and possible incarceration (Bradford, 2015; Flacks, 2017; Murray, 2014; Murray and Harkin, 2016). It is well established that adults are keen to exert spatial controls over youth (Valentine, 1996; Sibley, 1995), and that it is certain kinds of young people - the 'usual suspects' with an active street life - who are more vulnerable to police attention (McAra and McVie, 2005). Age, class, gender and race intersect to render young black and Asian men and boys particularly vulnerable to being detained (Eastwood, Shiner and Bear, 2013; Delsol and Shiner, 2015; Flacks, 2017). Although defenders of the tactics claim that stop and search involves only a minimum restriction of liberty or inconvenience to the suspect, studies have concluded that those youths who were stopped, questioned, warned or charged were much more likely to be arrested again, or display deviant behaviour than those

\footnotetext{
${ }^{9}$ HC Deb 12 July 2004 vol 423 cc1124-5

10 'Special Report: Knife crime and the battle for the streets', Sky News, 19 May 2017 https://www.youtube.com/watch?v=Gh6KP261-EM

11 West Midlands Police and Crime Commissioner (2014: 17).
} 
who had committed similar offences, but were still unknown to the police (McAra and McVie, 2005. See also Wiley and Esbensen, 2016: 299; CCR, 2012: 13; Bradford, 2015). Building on theory and evidence on labelling, (Lemert, 1967) this body of scholarship reinforces the argument that stop and search constitutes a first-line weapon in the relegation of some populations to slow-death existences through carceral punishment. Racial disproportionately in policing methods is reflected in rates of imprisonment; although they comprise only 14 per cent of the population, 25 per cent of prisoners - and 40 per cent of young people in custody - are from BAME backgrounds (MoJ, 2017). According to the Ministry of Justice (2017), the high proportion of young black people in custody is likely the result of higher arrest rates, custodial sentencing at the magistrates' court, and length of time spent in the custodial estate.

Second, in addition to the risks of criminalisation and imprisonment, researchers claim that stop and search has a "corrosive impact on social solidarity", leading to "feelings of exclusion, resentment, distrust of the police, alienation, social and, political disenfranchisement" (Bowling and Weber, 2011: 485). Young people express lower levels of trust and confidence in the police, can feel victimised because of their age and race, and are more vulnerable to harmful police encounters (Westley, 1953; Flacks, 2017; McAra and Mcvie, 2005; May et al., 2010). They also report feeling harassed, fearful and anxious as a result of stop and search, leading them "to reject any notion that they have value, save that which they derive from their own peer group." (Sharp and Atherton, 2007: 758; Reid Howie, 2001). While such consequences may, at first blush, seem harmful rather than destructive, they suggest that stop and search serves as an important tool for communicating to individuals that they 'don't belong'. People from a black background are more than twice as likely to live in poverty than those from a white background (Joseph Rowntree Trust, 2017), and recent figures found that Black Caribbean pupils were over three times more likely to be permanently excluded from school (DoE, 2017). Stigma, alienation, social position, education and racial discrimination, along with biological determinants, have been cited as explanations for inequalities in health in the UK, particularly in relation to race (Evandrou et al., 2016; Nazroo, 2003; Bécares, 2013). 
Thinking about political, public and judicial support for the discriminatory use of stop and search on young people in terms of necropolitics, and not simply in respect of efficiency, legitimacy or effectiveness, thus encourages reflection on how such powers operate, as part of a clutch of governing technologies, to diminish, subjugate and 'let die' some populations in the name of preserving the life and vitality of others. The Mohidin judgement - although largely finding in favour the claimants - provides an instructive example of how punitive, racist policing may be naturalised as a logical response to anxieties about young people in public spaces, and how stop and search functions as the 'opening gesture' in the securitisation of the city for the white, urban middle classes.

\section{Mohidin: the facts}

In Mohidin, three claimants - two of whom were aged 16 (Khan and Mohidin) and one 17 (Hegazy) at the time of the incident - had been falsely imprisoned and assaulted by police officers in the course of a stop and search encounter. Officers claimed that the search was conducted due to suspicion of drug activity, by far the most commonly cited justification for conducting a stop and search for both adults and under-18s (Eastwood, Shiner and Bear, 2013; Flacks, 2017). The claimants were awarded damages for the racial abuse, distress, humiliation and injury to feelings suffered. The allegations included claims of assault, unlawful searches both on the street and at the police station, and wrongful arrest. A long series of investigations by the Independent Police Complaints Commission (IPCC) and the Directorate of Professional Standards (DPS) at the Metropolitan Police resulted in no action being taken against any of the officers concerned. Several of the officers were also charged with criminal offences, including racially aggravated common assault and misconduct in a public office, but they were unanimously acquitted of all charges following a trial at Kingston Crown Court. Although there was some dispute about the precise circumstances leading to the incident, a van carrying six officers stopped at a junction in Central London due to the appearance and behaviour of a group of young people. Two of the claimants were subsequently arrested. They were children (under-18s, as stipulated by the Children's Act (s.1)), although there was no mention 
in the judgement of their special vulnerability or needs, or of any particular protection concerns that the officers should have availed themselves of during the encounter. ${ }^{12}$

There was some, disputed, evidence that the individuals had committed public order offences under section 4 or section 5 of the Public Order Act 1986 by obstructing the pavement, generally looking unruly and making gestures at the police van as it passed (para. 81). However, it was instructive that the officers chose - legally, according to the court and complaints bodies - not to detain the claimants on that basis and to deploy more intrusive stop and search powers in order to 'investigate' and ultimately discipline the suspects. Justice Gilbert concluded that the group had been followed due to "obscene gestures and insults" and because the officers "felt that a challenge had been made to them by a group they regarded as bad mannered and objectionable teenagers" (para 272). However, he did not criticise the decision to subsequently effect a stop and search even though there were no grounds to suspect that the claimants were carrying prohibited items. As discussed further below, this speaks to the utility of stop and search as a weapon that can effect more punitive ends than otherwise available, and to the impunity with which officers are able deploy the power.

\section{The occupation of public space}

A particular concern for the officers, repeated in different testimonies, was the sense that the young people (wrongly) acted as if they were entitled to occupy that particular public area. Sergeant Wilson said that he had heard someone making reference to one of the youths acting as if he "owned the Edgware Road" (para 187). At least one of the claimants was known to the police (para. 166), and there was reference to a previous stop and search of Basil Khan when he was seen walking down the Edgware Road "with his fist clenched and chest out" (para. 167). Geographers have remarked that there is an "association of spatial penetration with impurity" (Morley, 2000: 195), and that marginal "others" such as disruptive-seeming young people, are earmarked for removal in order to 'purify' public space. Race is

\footnotetext{
12 There was a passing reference to the strip search of one of the claimants, Khan, while in police custody, and that this breached Pace Code A because he was only 16 at the time (para 4).
} 
embedded in this process, particularly in London where the urban experience is contingent on ethnic grouping and socio-economic status (Graham and Marvin, 2001). The decision to strip-search of one of the claimants, Khan, later while in custody, was justified according to neo-rationalities of urban purification. Some officers alleged that he had threatened to stab tourists, and made threats to kill one of the police officers, charges that could potentially have resulted in a prison sentence. ${ }^{13}$ However, Justice Gilbart found no evidence to support this contention, adding that he was "satisfied that it was said to the custody sergeant so as to put Basil Khan in a deliberately worse light" (para 242). Studies of urban space and social control have emphasised the importance of attracting tourists to the success of the contemporary, neoliberal city. For city governments around the world intent on capital accumulation and racial/ethnic/class exclusion, under the auspices of 'effective governance' and 'global competition', tourism is a key source of revenue along with the privatisation of public services and real estate (Lipman, 2011; Hackworth, 2007). Attempts have therefore been made to cleanse the neoliberal city in high income nations in response to the desire for definitive boundaries and ordered living, thus keeping out "objects or people who do not fit the classification" (Sibley, 1995). The threat of undesirables, such as 'untidy' (read Black and Asian)looking young people, is thus a challenge to spatial hegemony (Malone, 2002: 161), and police are invested in the "cover[ing] up of unsightly visual blemishes" (Swanson, 2007, 723). In order for the 'right' urban image to be maintained for tourists and gentrifiers, city officials have concentrated on disciplining or removing those groups, behaviours and signs that unnerve the privileged social groups (Cook 2010). The threat to stab tourists, as well as an offence in its own right, enabled the framing of the behaviour of the young people as an attack on the city as a whole. It justified the need to exclude and reject the young people from an urban space in which they were constituted as 'out of place' (Kennelly, 2011), and to discipline them for disrupting the order of the commercial high street.

In his analysis of postcolonial necropower, Mbembe (2003: 25) observed that colonial occupation involved asserting spatial controls and giving meaning "to the enactment of differential rights to differing categories of people for different purposes

13 Offences against the Person Act 1861, s.16. 
within the same space; in brief, the exercise of sovereignty. Space was therefore the raw material of sovereignty and the violence it carried with it" (Mbembe, 2003: 25). Police powers such as stop and search are not deployed anew, as part of the creation or reshaping or territorial boundaries, but they are used in order to assert control over particular locations and to re-produce existing spatial relations.

Differential rights - to privacy, for example, and freedom of movement - are denied to populations depending on their age, gender and racial and economic background.

\section{'Bringing home the message': stop and search as racial punishment}

A notable feature of the case transcript is that, although the judge found that two of the claimants had been subject to racist abuse, the nature and significance of that behaviour merited relatively little comment. For example, in respect of Mohidin, when considering the level of damages, Mr Justice Gilbart observed that the racist abuse "caused him no significant effects thereafter" (para. 376). While rejecting a claim that damages for racial abuse should be reduced because of Mohidin's criminal record, he said that:

This is a classic case of a police officer failing to exercise proper judgment or discretion and allowing his temper to get the better of him, and in a particularly unpleasant way (para. 368).

In this way, the racial abuse was isolated and dismissed as the 'particularly unpleasant' result of poor decision-making, and failing to contain one's emotions, on the part of an individual officer (PC Jones), rather than behaviour that might demand further investigation in respect of either the officer(s) concerned or the police force in general. Although the accused officers all denied making racial slurs, PC Onwugbonu said that, after apprehending the group

PC Jones then asked Omar "where are you from?" Omar said "Kuwait". PC Jones then shouted at him saying words to the effect of "you're fucking here robbing people [while] our British soldiers are getting killed in Iraq" (para. 131). 
The conflation of Omar's national identity with the war in Iraq enabled his relegation to simply another form of 'animal life' (from an indistinct 'foreign' land), whose behaviour could be framed as an attack on the nation as a whole, and who shared no human bond with the police officers as domestic, 'occupying' forces (Mbembe, 2003: 24). As well as race, the age of the complainants also appeared relevant to the decision to inflict punishment. Sergeant Wilson described another officer as being "angry at a rude disrespectful schoolboy" (para 187) [my emphasis]. However, as noted above, age was also given scant consideration in court, and the word 'child' is used only once in the transcript (para. 200) with the judge preferring the term "teenage youth" (paras 40, 272). There was only one brief mention from the judge about the claimants' potential age-related vulnerability in respect of the officers' decision to force Basil Khan to kneel in the back of the police van (para. 296). The relevance of both the ages and race of the claimants was therefore minimised.

Recall that the investigation by the DPS into the incident, as well as the magistrates in an earlier hearing, found that the stop and search was justified. Although Justice Gilbart erred, he found that the search on Hegazy was unlawful because the officer failed to produce a warrant card, not because it lacked proper justification. He nonetheless conceded that it was "notable and curious" that Mohidin was not arrested for a public order offence, but instead searched for cannabis (para. 272). He added:

I do not believe that PC Jones intended to conduct a search for cannabis at all. His purpose was, and remained, bringing home to Omar Mohidin that he should not mouth obscenities or to make obscene gestures at the Police (ibid.)

The judge found that the search was part of an attempt to 'intimidate' Mohidin and to "bring the message home to [him] that conduct of the kind he had engaged in would be met with a vigorous response...[he]wanted to intimidate" (para 304).

The testimony of PC Brown was also remarkably frank about the decision-making process leading to the search of Hegazy. He went on: 
I told him that he would be searched. I opted for drugs. I suspected that he had a full wrap of some description. It is a red light area with lots of drug use. Nearby there is an apartment with a large car park known for drug dealing (para 136) [my emphasis].

'Opting' for drugs suggests retrospective reasoning rather than prior, reasonable grounds for suspicion, and neither would simply being in a 'red light area' pass the 'reasonable suspicion' test (Pace Code A (2.11), although it is not unusual for 'uncooperative' individuals to be searched for cannabis as part of maintaining police authority on the streets (May et al., 2002: 48-49). In any case, 'reasonable suspicion', while ostensibly restricting unfettered police action, affords exceptionally wide discretion to police officers. In the US, 'probable cause' is a similarly ambiguous criterion. It means:

damn good reason to believe:' that's all. Not certainty beyond a reasonable doubt, not even more likely than not. But [just] more than a hunch or [mere] suspicion. That's the best we can do to define it (Uviller, 1996: 49, cited in Sexton, 2007: 199)

Police also enjoy immunity from criminal prosecution even if stop and searches are found to lack reasonable suspicion, although they may be liable under the law of tort. As in Mohidin, monitoring bodies such as the IPCC often fail to hold police forces to account for damaging and/or racist police encounters. Although, according to Pace Code A, officers must ensure that their judgement is not based on "stereotyped images or inappropriate generalisations" (para 5.1) or "hunch or instinct" (para 2.6B) (HO, 2015), such guidelines have little legal force and, if breached, lead only to disciplinary proceedings that are rarely pursued (Zander, 2012). Given perennial evidence of disproportionality and the reluctance of disciplinary panels or courts, such as in Mohidin, to find such actions 'unreasonable' or hold officers to account, it might be asked whether such purported checks on police powers in fact serve to legitimise, rather than restrain, punitive policing activities. Relying on the state to provide protection against harmful policing through the rewriting of codes and the institution of renewed forms of monitoring thus potentially obscures the ways in which racist practices remain embedded in legal structures. 


\section{Authorising stop and search}

It has been suggested that the facts in Mohidin help to both illustrate the ways in which certain young people are considered ripe for exclusion, and elucidates the role of stop and search as a punitive technology. However, it is the legitimisation and authorisation of disproportionately-deployed stop and search powers by the judge, in the name of preserving or protecting the life and vitality of others, that warrants consideration of the support of such tactics as an instantiation of necropower. Basil Khan testified that as soon as he saw the police van, he feared that the group might be stopped and searched "because that often happened" (para. 80). As indicated above, this reflects the experiences of many young people who remain persistently targeted by police (Flacks, 2017; Murray, 2014), echoing Thacker's (2011: 158) observations about 'bare life' as "constantly rendered in its precariousness, a life that is always potentially under attack and therefore always an exceptional life." Yet, as mentioned above, Justice Gilbert went out of his way to quash concerns that the claimants had previously been subject to repeated negative stop and searches in the area, and that this should in any way justify their behaviour and feelings of frustration. He said (para. 40-41):

One must be realistic. If teenage youths go around together in a part of London which endures a fair amount of crime... it is not surprising that they have been stopped and searched many times. I do not treat the fact that they had been stopped and searched often without anything been found as being a matter for which the officers who had done so should be criticised. Policing an area such as this requires that the full range of measures is available for use, provided that sensible discretion and judgment is used...

The argument that officers should not be criticised for repeatedly stopping the 'usual suspects' without foundation authorises discriminatory policing methods. The harms caused to the claimants were isolated as individual failures of police behaviour; questions relating to systemic problems with young people's policing were repeatedly dismissed. To reiterate, the court's support for stop and search reflects a long history of a political and institutional defence of the powers. The Macpherson 
report, published following an inquiry into the racist murder of black teenager Stephen Lawrence, unambiguously condemned the disproportionate use of stop and search practices yet concluded that the powers should remain intact and that changes only be made to monitoring and administrative controls (Macpherson, 1999: Recommendation 60; Delsol and Shiner, 2006: 247). Recall that, in agreement with her all-white, almost entirely Oxbridge-educated colleagues, ${ }^{14}$ Lady Hale insisted in Roberts that stop and search powers provided "great benefits", particularly to black people who would gain from the protection afforded. As Sarah Lamble observes in a different context (sexual citizenship), imagining the police as protectors rather as

enforcers of the economic, political and racial hierarchies is contingent on a privileged social position. For young black youth in poorer boroughs who are regularly stopped and searched by police - whose peers have been shot, killed and brutalized by state authorities - the idea that the police are benevolent protectors is a white middle-class fantasy" (Lamble, 2013: 240).

Lady Hale's comments reverberate with the vestiges of the "continuing dilemma" for British colonial policing practices, which was to "persuade the indigenous population that it was not sufficiently advanced to sustain its own judicial practices and law enforcement procedures until it had absorbed the colonial legal construction" (Brogden, 1987: 10). She emphasised that it is the "randomness and therefore the unpredictability of the search which has the deterrent effect and also increases the chance that weapons will be detected." Yet it was explained to the court that stop and searches are not 'random', and that there remains a lack of support for any such 'deterrent effect', or for the effectiveness of such powers in addressing knife crime in general (Shiner, 2012). The comments of Lady Hale, a much-vaunted liberal protector of the rights of women and children, thus legitimised systematic oppression by reinscribing discriminatory policing as 'necessary' to protect some populations at the expense of others. Moreover, since police and crime commissioners are directly elected and scrutinised by local police and crime panels, Lady Hale insisted that accountability for the inappropriate use of section 60 searches is 'built in' to local democratic institutions. Yet given that under-18s cannot vote, young people's voices

14 Visit: https://www.supremecourt.uk/about/biographies-of-the-justices.html 
are absent from legal and political processes, potentially allowing for the unfettered interference with their rights.

The defence and promotion of stop and search often re-emerges in order to explain particular crisis points and offer plausible policy solutions to complex criminological predicaments. For example, despite evidence that stop and search may have helped cause the riots in 2011 (Lewis et al., 2011), it was claimed that a subsequent reduction in their use led to an increase in knife crime (Cafe, 2016). One of the first actions of the incoming Metropolitan police commissioner, Cressida Dick, in 2017 was to order an increase in the use of stop and search to tackle knife crime, claiming that the "vast majority" of the public were supportive of such measures, in spite of objections from equality experts (Townsend, 2017). The Mayor of London, Sadiq Khan, recently acknowledged that stop and search "can "cause community tensions" when "done badly", but added that "when based on real intelligence, geographically focused and performed professionally, it is a vital tool for the police to keep our communities safe" (Crerar and Davenport, 2018). Any problem with stop and search is thus reduced to its administrative and technical deployment, rather than its inherently-racialised dynamic. Although the reasons that young people carry knifes and engage in associated violent behaviour are complex (Holligan, 2014), and criminal justice responses and 'reassurance policing' may exacerbate the problem (Stephen, 2009; Squires, 2009) campaigners, politicians and police chiefs have routinely promoted longer prison sentences, more stop and search and tougher police measures to combat such behaviour (BBC, 2016; Bentham, 2017). The Sentencing Council has published draft guidelines for longer, mandatory sentences (SC, 2016), offering an apparently simple solution to the structural, spatial and political causes of knife crime.

\section{Conclusion}

Research into stop and search has mainly focused on how it fails in its purported goals (for example, the prevention of offending), and on the damage it does to individuals and communities. However, although there has been some reflection on what social function it might serve besides its ostensible role in fighting crime (Bradford and Loader, 2016; Harcourt, 2001), there is scope for further theoretical 
investigation. It is important to think about the stop and search of young people not simply as a temporary inconvenience or necessary evil, or even as a mere challenge to police legitimacy or police-community relations, but for the long-term effects on particular populations. The case of Mohidin illustrates the ways in which (some) young people's use of public space is problematized by police officers, and how stop and search powers function as a form of punishment as well as, or instead of, legitimate forms of crime detection. It has been argued in this paper that the judicial defence of such powers, and muting of objections to their racist and exclusionary effect, serves to authorise and legitimate the deathly logic of policing practice as part of a promise to preserve the security of citizens worthy of protection. The "almost mythical belief in [the] efficacy" of stop and search powers, in the face of consistent evidence to the contrary (Delsol, 2015: 79), might therefore be a function of the necropolitical investment in such tactics rather than the result of a dearth of rational policy-making or adequate legal safeguards.

Understanding the institutional defence of stop and search powers as an instantiation of necropolitics does not preclude the potential for resistance, such as by the young claimants in Mohidin or through attempts to better equip young people with the resources to enforce their rights in stop and search situations. ${ }^{15}$ Neither does it suggest that all recipients of stop and search powers are 'innocent' victims destined for death, whether physical or social. However, it does position the operation of such powers on young people within a broader analytic, placing the racial profiling of young people within the technologies and rationalities of governance where sovereign power over life and death is central. Whereas criminal justice measures, particularly regarding the young, have tended to be explained with reference to Foucault's elaboration of the 'disciplinary' society, it is his less frequently deployed (at least within criminology) understanding of biopolitics, and subsequent iterations, that may prove most fruitful in understanding the continued authorisation and legitimisation of stop and search powers. A necropolitical perspective can also help to cultivate a deeper understanding of how and why instruments of police brutality and abuses of power - especially when inflicted against black and minority

${ }^{15}$ Visit: http://y-stop.org/ 
communities across the world - continue to be authorised and legitimised in the face of perennial campaigns for reform.

\section{References}

Bear D. (2013) Adapting, acting out, or standing firm: understanding the place of drugs in the policing of a London borough. PhD thesis, The London School of Economics and Political Science (LSE)

Bécares L. (2003) Which ethnic groups have the poorest health? Ethnic health inequalities 1991 to 2011, Dynamics of Diversity: evidence from the 2011 census, ESRC Centre on Dynamics of Ethnicity (CoDE), available at: http://www.ethnicity.ac.uk/medialibrary/briefingsupdated/which-ethnic-groups-havethe-poorest-health.pdf

Bentham M. (2017) 'Mother's plea on knife crime in London after her son's killer is found guilty', Evening Standard, 25 Jan 2017, available at:

http://www.standard.co.uk/news/crime/mothers-plea-on-knife-crime-in-london-afterher-sons-killer-is-found-guilty-a3449261.html

Bernasconi R. (2010) 'The Policing of Race Mixing: The Place of Biopower Within the History of Racisms', Journal of Bioethical Inquiry 7 (2):205-216.

Bowling, B. and Phillips, C. (2007) 'Disproportionate and discriminatory: reviewing the evidence on police stop and search', Modern Law Review, 70 (6): 236-961

Bowling B. and Weber L. (2011) 'Stop and search in global context: an overview', Policing and Society, 21:4, 480-488

Bradford B. (2014) 'Policing and social identity: procedural justice, inclusion and cooperation between police and public' 24 Policing and Society 22 
- (2015) Unintended consequences. In: Delsol R and Shiner M (eds) Stop and Search: The Anatomy of a Police Power. Houndmills, Basingstoke: Palgrave Macmillan.

Bradford B. and Loader I. (2016) 'Police, Crime and Order: The Case of Stop and Search' in - Bradford B., Jauregui B., Loader I., Steinberg J. (eds.) The SAGE Handbook of Global Policing, London: Sage.

Brogden M. (1987) 'The Emergence of the Police: The Colonial Dimension', British Journal of Criminology, 27(1): 4-14

Brown E. (2014) 'Expanding carceral geographies: challenging mass incarceration and creating a "community orientation" towards juvenile delinquency', Geography Helvetica, 69, 377-388

Cafe R. (2016) 'London 2011 riots: Stop and search change 'led to knife crime', BBC news, 4 August 2017, available at: http://www.bbc.co.uk/news/uk-england-london$\underline{36964245}$

Cook, I. (2010) 'Policing, Partnerships, and Profits: The Operations of Business Improvement Districts and Town Center Management Schemes in England', Urban Geography, 31(4): 453-478

Delsol, R. and Shiner, M. (2006) 'Regulating stop and search: a challenge for police and community relations in England and Wales, Critical Criminology, 14 (3). pp. 241263

- (2015) Stop and Search: The Anatomy of a Police Power, London: Palgrave.

Demuth C. (1978) 'Sus', a report on the Vagrancy Act 1824, London: Runnymede Trust

Department of Education (DoE) (2017) Permanent and Fixed Period Exclusions 
in England: 2015 to 2016, accessible at:

https://www.gov.uk/government/uploads/system/uploads/attachment data/file/64507 5/SFR35 2017 text.pdf

Dodd V. (2017) 'Stop and search: police 'unacceptably slow' to comply with new rules', The Guardian, 2 February, 2017

EHRC (2010) Stop and think: A critical review of the use of stop and search powers in England and Wales, London: Equality and Human Rights Commission

Eastwood N., Shiner M. and Bear D. (2013) The Numbers in Black and White: Ethnic Disparities in the Policing and Prosecution of Drug Offences in England and Wales, London: Release.

Evandrou M, Falkingham J, Feng Z, et al Ethnic inequalities in limiting health and self-reported health in later life revisited J Epidemiol Community Health Published Online First: 19 January 2016. doi: 10.1136/jech-2015-206074

Foucault M (1976) The Will to Knowledge: The History of Sexuality Volume 1 (trans. R Hurley, 1998).

- (2003) Society Must be Defended: Lectures at the Collège de France, 1975-76: Lectures at the College De France, Trans David Macey, London: Pearson

- (2007) Security, Territory, Population: Lectures at the College de France, 19771978, edited by M. Senellart, F. Ewald, A. Fontana, and A.I. Davidson. Translated by G. Burchell. Basingstoke, England: Palgrave Macmillan

Fryer, P. (1984) Staying Power: The History of Black People in Britain. London: Pluto.

Gilroy, Paul (1997). ' 'Scales and Eyes: 'Race' Making Difference" ', in The Eight Technologies of Otherness. Edited by Sue Golding. London: Routledge. 
Goldson, B. (2008) 'Early Intervention in The Youth Justice Sphere: A KnowledgeBased Critique', In M. Blyth, \& E. Solomon (Eds.), Prevention and Youth Crime (pp. 89-104). Bristol: The Policy Press

Goldson, B., \& Coles, D. (2008) 'Child Deaths in the Juvenile Secure Estate', In M. Blyth, C. Wright, \& R. Newman (Eds.), Children and Young People in Custody (pp. 55-68). Bristol: The Policy Press.

Gossett C. (2014) 'We will not rest in peace: AIDS activism, black radicalism, queer and/or trans resistance', in Haritaworn, J., Kunstman, A., \& Posocco, S., eds. Queer Necropolitics, Abingdon/Oxon: Routledge

Graham S. and Marvin S. (2001) Splintering Urbanism: Networked Infrastructures, Technological. Mobilities and the Urban Condition, Routledge, London

Her Majesty's Inspectorate of Constabulary (HMIC) (2015) Best Use of Stop and Search Scheme - revisit of 19 forces; HMIC: London, available at:

http://www.justiceinspectorates.gov.uk/hmic/wp-content/uploads/best-use-of-stopand-search-scheme-19-forces-revisits.pdf

- (2015b) The welfare of vulnerable people in police custody, available at: http://www.justiceinspectorates.gov.uk/hmic/wp-content/uploads/the-welfare-ofvulnerable-people-in-police-custody.pdf

Hackworth, J. (2007). The neoliberal city: Governance, ideology, and development in American urbanism. Ithaca, NY: Cornell University Press.

Hannah-Moffat K and Lynch M (2012) Theorizing punishment's boundaries: An introduction, Theoretical Criminology, 16(2): 119-201.

Harcourt B. (2001) Illusion of Order: The False Promise of Broken Windows Policing. Cambridge and London: Harvard University Press. 
Haritaworn, J., Kunstman, A., \& Posocco, S., eds. (2014) Queer Necropolitics, Abingdon/Oxon: Routledge

Holligan, C. (2015) 'Disenfranchised Violent Young Offenders in Scotland : Using Actor-Network Theory to Explore an Aetiology of Knife Crime', Sociology, 49(1): 123138.

Howe, D. (1988) From Bobby to Babylon: Blacks and the British Police. London: Race Today

Publications

Innes M, (2004) 'Signal crimes and signal disorders: notes on deviance as communicative action' 55 British Journal of Sociology 335, 336

James J. (1996) Resisting State Violence, University of Minnesota Press

Joseph Roundtree Foundation (2017) Poverty rate by ethnicity, accessible at: http://www.jrf.org.uk/data/poverty-rate-ethnicity

Kennelly, J. (2011). Policing young people as citizens-in-waiting: legitimacy, spatiality, and governance. British Journal of Criminology, 51(2), pp 336-354.

Kojève A. (1980) Introduction à la lecture de Hegel - Leçons sur la "Phénoménologie de l'esprit" professées de 1933 à 1939 à l'École des hautes études, Paris: Gallimard

Lamble, S. (2013) 'Queer Necropolitics and the Expanding Carceral State:

Interrogating Sexual Investments in Punishment', Law and Critique, 24: 229.

Lemert, E. (1967) Human deviance, social problems and social control, Englewood Cliffs, NJ: Prentice-Hall.

Lewis, P. Newburn T. Taylor, M. Mcgillivray, C. Greenhill, A. and Frayman, H. Proctor, R. (2011) Reading the riots: investigating England's summer of disorder, The London School of Economics and Political Science and The Guardian, London, 
Lipman P. (2011) The new political economy of urban education: neoliberalism, race and the right to the city, New York, Routledge

Macpherson, W. (1999). Inquiry into the Matters Arising from the Death of Stephen Lawrence: Final Report. London: The Stationery O\ce

Malone, K. (2002). "Street life: youth, culture and competing uses of public space", Environment and Urbanization, vol. 14, no. 2, p. 157-168.

Martinot S and Sexton J (2003) 'The avant-garde of white supremacy', Social Identities 9(2): 169-181

May T, Warburton H, Turnbull PJ, et al. (2002) Times they are a-changing: Policing of cannabis. York: Joseph Rowntree Foundation

Mbembe A. (2013) 'Necropolitics’ Public Culture Winter 2003 15(1): $11-40$

McAra, L. and McVie, S. (2005) 'The usual suspects? Street life, young people, and the police', Criminology and Criminal Justice, 5 (1), 5-36.

Ministry of Justice (MoJ) (2017) Ministry of Justice, Exploratory analysis examining disproportionality of young black people (10-17 years old) in custody, accessible at: https://www.gov.uk/government/statistics/exploratory-analysis-of-the-youth-secureestate-by-bame-groups

Morley D. (2000) Home Territories. Media, Mobility and Identity. Routledge, London and New York

Murray K (2014) 'Stop and search in Scotland: An evaluation of police practice', SCCJR Report, 01/2014 
Murray K, Harkin D (2016) 'Policing in cool and hot climates: Legitimacy, power and the rise and fall of mass stop and search in Scotland', British Journal of Criminology 26(3): 885-905

Nazroo JY (2003) The structuring of ethnic inequalities in health: Economic position, racial discrimination, and racism. Am J Public Health 2003; 93:277-84

Prison Reform Trust (2008) Criminal Damage: why we should lock up fewer children, London: Prison Reform Trust, available at:

http://www.prisonreformtrust.org.uk/Portals/0/Documents/CriminalDamage.pdf

Reid J. (2008) 'Life struggles: war, discipline, and biopolitics in the thought of Michel Foucault' In Michael Dillon \& Andrew W. Neal (eds.), Foucault on Politics, Security and War. Palgrave-Macmillan.

Reiner R. (2010) The Politics of the Police (4 ${ }^{\text {th }}$ ed.), Oxford: OUP

Rose N. (1990) Governing the Soul: The Shaping of the Private Self. London: Routledge.

Scraton, P., and McQulloch J. (eds.) (2009) The violence of incarceration. London: Routledge

Sentencing Council (2016) Bladed Articles and Offensive Weapons Guideline Consultation, London: Sentencing Council, https://www.sentencingcouncil.org.uk/wpcontent/uploads/Bladed-articles-and-offensive-weapons-guideline-consultationweb.pdf

Sexton J. (2007) 'Racial Profiling and the Societies of Control', in James J. ed. Warfare in the American Homeland: Policing and Prison in a Penal Democracy, pp. 197-218. Duke University Press: Durham, NC

Shiner M. (2010) 'Post-Lawrence Policing in England and Wales: Guilt, Innocence and the Defence of Organizational Ego', Br J Criminol 50 (5): 935-953 
- (2012) Report on the use of section 60 of the Criminal Justice and Public Order Act 1994 by the police, Expert Witness Statement, available at: http://www.stopwatch.org/get-informed/research/report-on-the-use-of-section-60-of-the-criminaljustice-and-public-order-ac

- (2015) 'The Politics of the Powers' in Delsol R and Shiner M (eds) Stop and Search: The Anatomy of a Police Power. Houndmills, Basingstoke: Palgrave Macmillan

Sibley, D (1995), Geographies of Exclusion, Routledge, London.

Squires, P. (2009) 'Beyond the mainstream: the knife crime 'epidemic' and British politics' British Politics, 4 (1). pp. 127-157.

Steinert H. (2003) 'The Indispensable Metaphor of War: On Populist Politics and the Contradictions of the State's Monopoly of Force', Theoretical Criminology, Vol. 7(3): 265-291

Stephen D. (2009) 'Time to stop twisting the knife: a critical commentary on the rights and wrongs of criminal justice responses to problem youth in the UK', Journal of Social Welfare and Family Law, 31(2)

Stoler, A.L. (1996) Race and the education of desire. Durham: Duke University. Thacker, E. (2011) 'Necrologies or the Death of the Body Politic', in Clough and Wilse (eds.) Beyond Biopolitics, Durham and London: Duke University Press.

Townsend M. (2017) 'Stop and search won't help to beat knife crime, Met chief is told', The Guardian, available at: https://www.theguardian.com/uknews/2017/may/20/stop-and-search-cressida-dick-knife-crime

Valentine G. (1996) Angels and devils: the moral landscape of childhood. Environment \& Planning D: Society and Space, 14, 581-599. 
Valverde M. (2009) "Beyond Discipline and Punish: Foucault's challenge to criminology" in Carceral Notebooks vol. 4, 201-224.

Weber L. (2011) 'It sounds like they shouldn't be here': immigration checks on the streets of Sydney, Policing and Society, 21:4, 456-467

Weber L. \& Bowling B. (2011) Stop and search in global context, Policing and Society, 21:4, 353-356

- (2008), 'Valiant beggars and global vagabonds - Select, eject, immobilize,' Theoretical Criminology, vol 12, no. 3: 355 - 375

Westley WA (1953) 'Violence and the police', American Journal of Sociology 59: 3441.

West Midlands Police and Crime Commissioner (2014) Stop and Search Action Plan - Outcome of Consultation, available at: http://www.westmidlands-

pcc.gov.uk/media/271796/14-spcb-07-jan-14-stop-and-search-action-plan-outcomeof-consultation.pdf

Stephanie A. Wiley, \& Finn-Aage Esbensen (2013) 'The Effect of Police Contact: Does Official Intervention Result in Deviance Amplification?' Crime \& Delinquency, 62(3): $283-307$

Zander M. (2012) 'If the PACE Codes Are Not Law, Why Do They Have to Be Followed?', Criminal Law and Justice Weekly, available at: https://www.criminallawandjustice.co.uk/features/If-PACE-Codes-Are-Not-Law-WhyDo-They-Have-Be-Followed

Zedner L. (2016) 'Penal Subversions: when is a punishment not a punishment, who decides, and on what grounds?' 20 Theoretical Criminology 3 